\title{
Participatory Action Research: Confidentiality and Attitudes of Victimized Young People Unknown to Child Protection Agencies
}

\author{
Laurie Matthew $^{1}$ (D) $\cdot$ lan Barron ${ }^{2} \cdot$ Ann Hodson $^{3}$
}

Accepted: 5 June 2019 / Published online: 4 July 2019

(C) The Author(s) 2019

\begin{abstract}
This study explores views of young child abuse survivors, whose abuse was unknown to child protection, about confidentiality. Survivors involved with charity Eighteen And Under $(n=185)$ were invited to participate. A total of 140 participated. Eight aged 12-20, two males and 6 females chose involvement as researchers and participants and 132 aged 11-30, 25 males, 114 females and one non-gendered chose participant involvement. Eighty-five percent $(n=117)$ were survivors of child sexual abuse and $15 \%(n=23)$ were survivors of child abuse. Utilizing participatory action research, researchers designed and analyzed qualitative and quantitative data gathered through surveys, interviews, focus groups, online-chats and graffiti walls. A social construction thematic approach analyzed data. Inter-rater reliability was maximized through independent data analysis. The results showed that participants, particularly males and under $16 \mathrm{~s}$, wanted greater protection of confidentiality. Males were less likely to disclose sexual abuse. Two superordinate themes were identified: (a) limited confidentiality led to fear of loss of control and trust and (b) retractions of abuse and higher levels of confidentiality led to talking openly, feeling respected and believed and a sense of control and empowerment. Two further themes were identified from young researcher reports: improved self-esteem and positive life changes. In conclusion, young people unknown to services want greater confidentiality than is currently offered. Participative research was emancipatory, and further participatory research with young CSA survivors is needed.
\end{abstract}

Keywords Confidentiality $\cdot$ Child sexual abuse $\cdot$ Young people $\cdot$ Participatory $\cdot$ Child protection

Prevalence rates of child sexual abuse (CSA) vary depending on definitions, populations and methodologies. Incidence figures for CSA range from 0.1 (Morgan and Kena 2018) to $7 \%$ (Flatley 2016); compared with prevalence statistics with a range of 11.3

Laurie Matthew

lormac1053@aol.com

Extended author information available on the last page of the article 
(Radford et al. 2011) to 21.1\% (Hébert et al., 2009) and 81\% (Priebe and Svedin, 2008). In addition, research has indicated that young CSA survivors present a distinctive victimological profile having previously experienced other forms of victimization (Pereda et al. 2016). The difference in incidence and prevalence figures suggests CSA is under-reported and under-recorded (Reitsema and Grietens 2016).

Reporting CSA in childhood is risky and traumatic with uncertain outcomes and negative experiences for survivors (Jonzon and Lindblad 2004). Ullman (2007) concluded that negative outcomes following CSA disclosure are more likely in childhood than adulthood. Studies of teenagers found that which examined barriers to disclosure included fear, lack of confidentiality, lack of trusting relationships, negative responses, fear of authorities and shame (Ungar et al. 2009). Of those who reported CSA, only $8.3 \%$ had talked to professionals (Priebe and Svedin, 2008).

One potential conclusion to reach the following analysis of studies of child disclosure of CSA and agency responses is that young CSA survivors' needs for safety and justice in the United Kingdom are insufficiently addressed by child protection services (CPS) and criminal justice systems (CJS) (Horvath et al. 2014; Allnock 2015). Even worse, survivors, already traumatized by abuse, are often re-traumatized by the systems created to investigate crime and punish abusers (Plotnikoff and Woolfson 2009; Weinstein 2014). Numerous studies indicate that this negative experience can cause long-term harm affecting health, education and family and inhibit young people from engaging with CJS processes in the future (Zajac et al. 2012; Gekoski et al. 2016; Munro 2010, 2011a, b). The result is vulnerability to further abuse.

In contrast, relationships of trust between professionals and young people are vital in enabling young people to explore risky behaviour and address abuse (Smeaton 2013; Gilligan 2016). Hallett (2013) argued that trust is built when a young person feels that rights, confidentiality and views are respected. When these rights are not applied within child protection investigations, trust is further eroded. Indeed, such difficulties can lead vulnerable young people to be further entrapped within an abusive relationship (Gekoski et al. 2016; Hallett 2013). When there is an over-focus on safeguarding, there is a danger of losing sight of young people's rights and agency to the overall detriment of young people's health and well-being (Lefevre et al. 2017).

\section{Confidentiality}

Although research into young people's views on confidentiality is limited, the context of confidentiality may be particularly important to young people who are being victimized (Hill and Wales 2011; Matthew et al. 2019). Related issues such as trust and staying in control seem to arise from having confidentiality in the first place (Crisma et al. 2004). Although young people know confidentiality with most services is conditional on policies (Thomas et al. 2006), they are often uncertain as to the limitations of confidentiality (Hiriscau et al. 2014). Such ambiguity is not surprising because definitions of confidentiality vary across services, and guidance for workers is most often based around instances when confidentiality could or should be breached (British Medical Association 2015-16). 
The concepts of privacy and confidentiality are related but not the same. Privacy (Beauchamp and Childress 1994) relates to facets of a person's being that no one should intrude into or interfere with (Dhai and Payne-James 2013). Confidentiality is a relationship of trust during which a person shares private information with the expectation that it will not be shared without consent (Koggel 2003). Between research and practice, confidentiality is defined differently. In research, participants have a relationship of trust and expect researchers not to divulge information without permission (Boruch and Cecil 1979). Within social work, confidentiality is the professionals' duty not to talk about things owned by clients (Wilson 1978) and a commitment that nonpublic information will not be disclosed (Daniel and Kitchener 2000). Confidentiality allows people opportunity to discuss difficult issues safely, with clients giving up their privacy and trusting in confidentiality so as to receive help (Bisman 2008).

There is no mandatory reporting in the UK. Child protection systems in Scotland follow a broadly public health approach under 'Getting it Right for Every Child' (GIRFEC: Scottish Government 2012), now enshrined in the Children and Young People Scotland Act (2015). GIRFEC is an approach trying to improve outcomes through public services that supports children's wellbeing. Based on children's rights, it supports children, young people and their parents to work in partnership with services. It does not, however, allow for the right to confidential services. Rather, according to pressure groups such as Say No 2 Named Person (NO2NP), it allows vast amounts of information about children to be shared in the name of child protection and leads to a universal surveillance policy (Llewellyn Jones 2013).

\section{Research Involving Service Users}

Research with young abuse survivors, particularly CSA survivors is rare. Rarer still are studies exploring their views of confidentiality. Further, there are even fewer studies involving survivors as researchers despite research evidence that involving participant researchers leads to deeper understanding of participants' needs (Bevan 2013). According to Beresford (2010), traditional research values neutrality, objectivity, and researcher distance and, as a result, automatically devalues knowledge of those with lived experiences (e.g., CSA survivors) while elevating knowledge claims of academicians. Conceptualizing knowledge in this way suggests that survivors can be regarded as being too close to the problem and that their knowledge can be dismissed as less reliable (Beresford and Boxall 2014).

In contrast, Rose (2009) suggests that a traditional view is based on an assumption of knowledge production where the researcher has no influence on the knowledge that is produced during research. She argues that all researchers come from a particular stance with their own thoughts, beliefs, and values and challenges the hierarchy of credibility that places their knowledge ahead of service users. Beresford and Boxall (2013) argue that such a reframe of researcher and participant positionality creates new opportunities for people with lived experiences to generate new research knowledge. 


\section{Participatory Action Research}

Participatory action research (PAR) is one methodological approach that seeks to relocate the positioning and involvement of service users in research. Clemens and Mason (2008) evidenced PAR to be empowering, healing and challenging of inequality when used with abuse survivors. Research with adult survivors (Matthew and Barron 2015) led to transformational change for the survivors, such as securing paid and unpaid work and taking up further education. According to Silver (2011), PAR differs from other forms of research because lay people are involved as experts informing action. Also, a participatory approach is thought to be more respectful of the people being researched as it involves researching with the person rather than extracting information from them (Beazley and Ennew 2006).

There are challenges to consider while undertaking PAR with young people. First, lack of knowledge and competency because of immaturity, is a barrier often cited (Kellett 2005, 2009, 2010). However, there is a growing body of evidence contesting this assumption and suggesting, when treated as equals, young people can participate effectively and take ownership of research (Gray and Winter 2011). Young people have been shown to be knowledgeable and competent researchers in a health study (Bergström, et al. 2010). Kellett (2010) found that young people generate data that differ from those produced by adults because their perspectives, questions and communication methods differ. Findings were discovered to be from a unique youth perspective that differs from adults' interpretation of meaning (Lundy et al. 2011). For example, young people were able to provide insightful reasons underlying responses to questions. However, there is a danger that young people as researchers might over-identify with peers, so that they become enshared in potentially challenging situations, such as becoming emotionally or financially involved (Jones 2004). Finally, young people and CSA survivors are not a homogenous group (Punch 2002), so that there can be as many differences as there are shared experiences with any group or category of people (Orne and Bell 2015).

\section{Methods}

\section{Research Aims and Design}

Research approval was granted by the University of Dundee Research Ethics committee (reference: E2016-12) to explore the views of young CSA survivors whose abuse was unknown to child protection agencies on confidentiality. Young people gave their own consent to participate and could withdraw from the study at any time without consequence. PAR involving young CSA survivors as researchers was utilized to enable fuller participation and empowerment of young people, so that participants (CSA survivors) could become involved to whatever level they chose: designing data collection tools, collecting and analyzing data, reflecting and disseminating findings, and action (Kesby et al. 2005).To involve young CSA survivors fully, it was important to stay flexible and open in selecting methods of inquiry. This meant using a mixedmethod approach to gather both qualitative and quantitative data (Piano-Clark and Creswell 2008). This approach provided a sufficient quantity of data to identify patterns 
while having in-depth qualitative information to add richness and deeper meaning to the data. The methodology moved over time towards qualitative and social constructionism (Punch 2009), as survivor researchers sought more in-depth information and became immersed in teasing out themes and issues.

Recruitment of co-researchers by the principal researcher involved publicising the study, providing information about the study, training in research methods and ethics, and providing support to enable them to fully participate as researchers. The principal researcher also ensured that all data were stripped of identifiers prior to being shared with the young researchers, so that confidentiality of participants was maintained. Coordination, continuity and communication throughout the research were managed by the principal researcher, who also transcribed and recorded results.

\section{Participants}

Established in 1994, Eighteen And Under (18u) is a charity based in Scotland. It provides long-term confidential support to abused young people. Confidentiality provided by $18 \mathrm{u}$ means that no information at all is shared with other agencies or individuals, even in cases of ongoing abuse. The young person remains in control throughout. Confidentiality is not based on age. Rather, any young person capable of finding the service and requesting confidential support receives it. Support is provided online, by text, through social media and face-to-face. Crisis drop-in services are providing evenings and weekends, and street work is carried out to reach vulnerable young people. All participants were recruited from within $18 \mathrm{u}$. Recruitment of participants was carried out through advertising within the $18 \mathrm{u}$ centre and on the $18 \mathrm{u}$ website and support forum. Young people were free to choose their own involvement.

A total of 140 young people took part in the research as participants. Twenty-five were male, 114 were female and one was non-gendered. Ages ranged from under $12 \mathrm{yr}$ $(n=3)$ 25-30 yr $(n=3)$, with most aged between $12-15 \mathrm{yr}(n=47)$; and 16-18 yr $(n=45)$. A total of $95(68 \%)$ were aged 18 or under. Age groups 19-21 yr $(n=19)$ and $22-25 \mathrm{yr}(n=23)$ were also represented. Ten participated in interviews, 96 in surveys, 18 in two focus groups with eight in one focus group and ten in the other, eight in online chats, eight as researchers and an unknown number on Graffiti Walls provided 52 comments.

\section{Young Researchers}

Eight young people out of 12 who attended initial meetings aged 12-20 self-selected as young researchers and also as participants. Six had been diagnosed with mental health problems, four were registered disabled and two had mild learning difficulties. One attended school, two were at school age but not in school due to mental health problems such as panic attacks and anxiety and one attended College. Two identified as male and six as female; three had been in local authority care and one was still in care.

\section{Procedures}

Young researchers attended three training events to learn about ethics, research questions, methods and data analysis. Meetings were held on-line and face to face 
weekly to discuss ideas, thoughts, ethics, goals, methods and research procedures. Researchers were invited throughout to provide feedback on their involvement, personal experiences and views of the research process. The young researchers helped design data collection survey questions, which were piloted before use by four young survivors who attended an art activity in $18 \mathrm{u}$ but were not involved in the research. The language in two questions was reworded after the trial to make them more youth-friendly. Information about the study and methods of involvement were provided on $18 \mathrm{u}$ Facebook, noticeboards and online forums and shared directly with young people.

\section{Interviews}

Semi-structured interviews using the survey questions were conducted and digitally recorded by the principal researcher to protect confidentiality. Survivors could choose how and where they were interviewed. Skype, instant message (IM), live chat or faceto-face all were offered. One person chose face-to-face and nine selsected IM. Using IM meant that young people could answer questions in their own time. Some $(n=6)$ took several days to think through questions and complete their interview. After answering, Some $(n=2)$ took time to think and sent more IMs to explain their answers. Young people taking time to answer and providing further explanations led to a clearer understanding of what they were sharing. Ten CSA survivors aged between 15 and 18 yr were interviewed. Nine were female, and one was male. Four were in local authority care, and six had mental health problems diagnosed by professional, (mostly PTSD and depression caused by abuse). Identifier were removed before data were shared with all researchers.

\section{Surveys, Blogs and Social Media}

Online surveys, blogs and social media were used to gather anonymous views. There were 12 questions. Seven were open-ended, two used a Likert scale and one used a ranking scale of importance. Social media are increasingly used in surveys. If questions are clear and have been piloted, this can be a reliable way of gathering information (Moy and Murphy 2016). Among young people, Facebook is the most popular social media platform (Mascheroni and Ólafsson 2014), followed by Instagram, WhatsApp and Snapchat. In line with this finding, social media were used extensively in the study by the young people. Nine young people used social media for interviews, 10 for the focus group, eight used online group chat and 96 used the online survey.

\section{Focus Groups}

Research suggests online focus groups are as effective in gathering quality data as are face-to-face focus groups (Im and Chee 2006). Woodyatt et al. (2016) suggested that they may yield more personal data on sensitive issues. As CSA is a sensitive issue, this characterisctic suited the study. Additionally, online forums have the advantage of permitting greater anonymity (Ybarra et al. 2014). Being open to both face-to-face and online focus groups was important to allow greater participation for those unable to attend in person. Two young researchers, with support from the principal researcher 
conducted focus groups, one online and one face-to-face with eight young people involved in the online group and ten in the face-to-face group. The survey questions were utilized, and discussions were recorded and transcribed.

\section{Graffiti Walls}

Large sheets of paper, pens and information about the study were made available in $18 \mathrm{u}$ toilets, to protect anonymity of those taking part. The title on the sheets was 'your views on confidentiality' and young people were invited to comment.

\section{Data Analysis}

A social constructionist perspective was used to analyze and make sense of the lived experience of young CSA survivors (Ashworth 2003). According to Braun and Clarke (2006), thematic analysis is a relatively straightforward form of qualitative analysis that does not require detailed and technical knowledge, and thus is a good approach for less experienced researchers.

Analysis became cyclical as researchers repeated the research phases six times (Ely et al. 1997). Researchers were immersed in data as it emerged, reading and re-reading, listening to recordings, matching against transcripts and searching for patterns of meaning. For inter-rater reliability, each researcher examined the data separately, then all came together to share codes, notes and agree themes. Once themes were identified, they were reviewed against codes over the entire data set, and a thematic map was generated.

\section{Results}

Although there were six different ways young people could be involved, most young people $(n=96)$ chose involvement through anonymous survey. This provided mostly quantitative data, but also qualitative information. Involvement through online chat, focus groups, interviews and as researchers provided most in-depth and qualitative data.

All young people who took part identified as abuse survivors, with $85 \%(n=117)$ identifying as CSA survivors; 24\% ( $n=33)$ experienced bullying; 20\% $(n=27)$ physical abuse; $12 \%(n=17)$ neglect; $11 \%(n=16)$ emotional abuse and $4 \%(n=6)$ experienced domestic abuse. Some young people had experienced multiple forms of abuse.

All participants aged under 12 reported being bullied, but as the ages increased, reports of bullying reduced to zero. Reports of physical abuse showed a similar trend with higher rates of reporting among younger people and reporting of physical abuse reducing as age increased. In contrast, no under 12's reported CSA, but CSA reports increased with age. A higher percentage of females $95 \%(n=108)$ reported CSA than males $32 \%(n=8)$. Males reported higher percentages of physical abuse $40 \%(n=10)$, bullying $52 \%(n=12)$ and neglect $20 \%(n=5)$ compared with females reporting physical abuse $15 \%(n=15)$, bullying $18 \%(n=20)$ and neglect $11 \%(n=12)$. No 
younger males reported CSA and the highest number of males reporting CSA $(n=4)$ were aged 22-25.

Confidentiality was defined by young people as complete privacy and a secret that should not be shared with anyone else: 'confidentiality to me means that when I share something, it will not be disclosed to anyone else under any circumstances' (girl aged 16).

Young people graded how confidential they thought services such as social services, health and education should be, using a Likert scale. All wanted greater confidentiality than services currently offered; $77 \%(n=106)$ wanted total confidentiality; $14 \%$ ( $n=$ 19) almost total confidentiality and $9 \%(n=13)$ wanted more confidentiality than is currently provided. Ninety percent $(n=45)$ of young people under 16 and all bar one male wanted absolute confidentiality. Confidentiality was ranked as the most important requisite for discussion of personal issues, with confidentiality the most important quality to building trust. Seventy percent of young people said either confidentiality should never be broken $(70 \%, n=92)$ or $11 \%(n=15)$ thought it should only be broken with their permission. Nineteen percent $(n=25)$ who thought it might be broken in some situations agreed it should be only in life-threatening or situations when another child was in danger, but they wanted their own information to remain private.

'My story is my business and I would never want someone to take it further, that's why people are scared to speak up, because they fear they would lose control of the situation. If I was to tell someone something that caused them concern, I would hope they would encourage me to take it further instead of the decision being made for me' (girl aged 17).

\section{Experiences of Confidentiality}

Young people reported varied life experiences of confidentiality with $69 \%$ ( $n=$ 96) remaining silent for fear there would be none; $31 \%(n=44)$ had experience of confidentiality being breached, and $30 \% \quad(n=42)$ had experienced high confidentiality. The themes for those who remained silent because they fear not having confidentiality and those who had experienced a breach of confidentiality were the same: fear of consequences, loss of privacy, loss of control, loss of trust, retraction of allegation and protecting the abuser (Table 1). Eightyone percent $(n=114)$ feared the consequences of talking about abuse. Some of this fear was based on lived experiences.

Loss of privacy led to further risks with loss of control and trust causing difficulties. Young people were not always safe from parents or when living in care, and the CJS and CPS process was overwhelming and damaging for those who had experience of it. Some young people who said nothing for fear of losing confidentiality $(n=9)$ and young people who had had confidentiality broken $(n=8)$ spoke about retracting what they had said about abuse. There was a desire to protect the abuser in several young people who said nothing for fear of losing confidentiality $(n=10)$ and young people who had had confidentiality broken $(n=8)$. Reasons given were not wanting the abuser punished $(n=$ 3 ) and loving the abuser $(n=7)$.

Themes for those with experience of services remaining confidential were: being able to talk openly, trust, empower, time to think, explore options, get abuse stopped, 
Table 1 Experiences of no confidentiality or broken confidentiality

\begin{tabular}{lll}
\hline Theme & Said nothing for fear it might not stay confidential $(\%)^{*}$ & Confidentiality broken $(\%)^{*}$ \\
\hline Fear of consequences & $114(81)$ & $50(35.7)$ \\
Privacy loss & $30(21)$ & $26(17.5)$ \\
Lost control & $24(17)$ & $12(8.5)$ \\
Lost trust/no trust & $7(5)$ & $22(15.7)$ \\
Retracted & $9(6)$ & $8(5.7)$ \\
Lies & $8(5.7)$ & $7(5)$ \\
Protecting the abuser & $10(7)$ & $8(5.7)$ \\
\hline
\end{tabular}

*Young people could provide more than one answer based on multiple experiences therefore totals vary and percentages are based on total number of young people $(n=140)$

respect and reduce isolation (Table 2). 'Trust is the key issue for a survivor because they have been so badly betrayed by all the adults who were supposed to protect and take care of them' (girl aged 18).

Being able to talk openly in confidence $(n=30)$ made a difference with young people feeling relieved and able to disclose abuse. A need to stay in control was expressed $(n=14)$ by young people who had never felt in control of their lives before, while some young people $(n=10)$ regarded having confidentiality as vital to building trust so as to be honest about what was going on for them.

Young people also talked about respect, equality and rights $(n=6)$ describing this in terms of being listened to, not judged and believed. Having control over what they said empowered some young people $(n=6)$ to take action for themselves and some needed to be in control $(n=3)$ so as to stop feeling like a victim and begin to identify as survivors ( Tables 3 and 4).

The young researchers reported: feeling more confident, positive life changes, enjoying the process and stated they felt empowered by the experience. 'No one listened to me before so I didn't know I could be a researcher and do

Table 2 Experience of confidential services

\begin{tabular}{ll}
\hline Theme & Kept confidential for the young people $(\%)^{*}$ \\
\hline Able to openly talk/tell about abuse & $30(71.4)$ \\
Trust and confidence building & $20(47.6)$ \\
Stay in control/empowered & $14(33)$ \\
Time to think & $10(23.8)$ \\
Explore options & $12(28.5)$ \\
Get abuse stopped & $10(23.8)$ \\
Respect & $6(14.2)$ \\
Reduced isolation & $5(11.9)$ \\
\hline
\end{tabular}

*Only 42 young people answered this question and they could give more than one answer therefore percentages do not add up to 100 
Table 3 Silent for fear of no confidentiality or confidentiality being breached

Theme Quotes from young people

Fear of consequences

School teachers/head of years got social services involved and my parents lied and stuff got worse, (girl aged 14).

When they share information, it goes too far, damaging people and relationships, (girl aged 15).

Loss of privacy

It got back to my parents and they were the problem, (boy aged 15).

The fear of finally being able to open up to someone and you ending up in a worse position is scary, (girl aged 17).

Loss of control You feel like you have lost all control for the situation just like when you get abused, (girl aged 17)

Lack of trust You cannot trust most people and especially not police, social work or teachers, (girl aged 14).

I told my friend and my friend told the school and then the school told social services, then social workers got involved with my parents, and it was just awful, (girl aged 15).

Lack of safety They told my mum everything I told them and I found that was worse. I know now not to tell, (girl aged 15).

I'm in care so have no control over my life so having some control over what I'm able to say is important to me, (girl aged 16).

Overwhelmed by the The police would not leave me alone. They said he had abused another girl so I had to process tell them. I could not do it. I was cracking up, (girl aged 17).

They would not stop asking questions about it. I just could not take it anymore, (girl aged 18).

Retraction of allegation

Lies of adults

started to tell a teacher and next thing I knew everything kicked off, my parents were called, the police were called and the whole thing got out of hand. I had enough of it and could not do it no more, (girl aged 16).

When I first told what was happening it was to an adult I was close to but not a professional and she lied and went straight to the police without my permission, (girl aged 16).

Protecting the abuser I do not want him in jail, (girl aged 16).

It does not matter what he did to me, I love him, (girl aged 14); Everyone says it's wrong because he is 28 and I'm 14 but I love him and I know he loves me too, (girl aged 14)

something important but, you know what? I really can' Z, aged 17. 'It's not just me it's happened to so I have to do something to stop it' (L, aged 17).

\section{Discussion}

This study is unique in involving a high number of young CSA survivors, whose abuse was unknown to authorities, and eight young abuse survivors as co-researchers in PAR. The study gives a voice to victimized young people whose views on confidentiality were also unknown. Further, the involvement of young survivors as researchers has provided a unique opportunity to learn from young survivors' perspectives.

This study found high numbers of young CSA survivors wanting complete or almost total confidentiality, indicating that confidentiality is important to 
Table 4 Experience of confidential services

\begin{tabular}{|c|c|}
\hline Theme & Quotes from young people \\
\hline $\begin{array}{l}\text { Able to talk openly in } \\
\text { confidence }\end{array}$ & $\begin{array}{l}\text { Knowing it was kept private allowed me to tell about abuse, (girl aged 14). } \\
\text { It was such a relief being able to talk about it at last, (girl aged 15). }\end{array}$ \\
\hline Staying in control & $\begin{array}{l}\text { I myself never felt in control of anything in my life when I was abused so knowing } \\
\text { I was in complete control over what I talked about was extremely important, } \\
\text { (girl aged 17). }\end{array}$ \\
\hline Building trust & $\begin{array}{l}\text { I think young people should have a confidential service so that they can feel a } \\
\text { sense of trust and feel more comfortable and honest when opening up about } \\
\text { difficult things, (girl aged 17). } \\
\text { Trust is the key issue for a survivor because they have been so badly betrayed by } \\
\text { all the adults who were supposed to protect and take care of them, (girl aged } \\
\text { 18). }\end{array}$ \\
\hline Equality and rights & $\begin{array}{l}\text { Just because I'm not an adult does not make it ok. I am a person too, (girl aged 13). } \\
\text { It is really important to me to have rights and confidential services is a right, (boy } \\
\text { aged 15). I want to be respected as a person the same as other people, (boy aged } \\
\text { 14) } \\
\text { Friendship, being equal and knowing that they will not tell anyone is most } \\
\text { important, (girl aged 14). }\end{array}$ \\
\hline $\begin{array}{l}\text { Control and } \\
\text { empowerment }\end{array}$ & $\begin{array}{l}\text { Knowing it was kept private allowed me to tell about abuse in the end, (girl aged } \\
\text { 16). } \\
\text { Then I decided he was not going to get away with what he did to me. He should be } \\
\text { punished. I reported it to the police, (girl aged 17). } \\
\text { You know what? I never thought about resisting him before. A simple wedge } \\
\text { under my door did the trick, (girl aged 16). }\end{array}$ \\
\hline
\end{tabular}

them. There was a correlation between age and the degree of confidentiality wanted with the youngest survivors and males wanting the highest degree of confidentiality. Young people were also explicit that this was one of the main reasons they did not disclose abuse. It is well documented that CSA survivors delay reporting abuse or never disclosed at all, especially in childhood and adolescence. Based on a review of contemporary studies of CSA disclosure rates, London et al. (2008) concluded that around 55 to $69 \%$ of CSA survivors never disclosed as children. Population studies from Canada and the USA agree, with between 70 and $75 \%$ of respondents waiting 5 years or more before disclosing. In addition to delaying disclosure, children often deny abuse happened, despite evidence such as medical findings suggesting otherwise (Lyon 2007) or evidence existing through video or photographic evidence (Sjöberg and Lindblad 2002).

Disclosing abuse is an inter-personal event rather than a decision to tell (Staller and Nelson-Gardell 2005) and a process requiring privacy, purpose and understanding (Jensen et al. 2005). Close relationships play an important part in allowing young people to talk and disclose (Priebe and Svedin 2008) and from what young survivors have shared in this study, it would seem relationships built on trust, confidentiality and respect are essential to this process.

The current study showed a difference in abuse reporting based on gender and age with males reporting more physical abuse than females, perhaps because it is more 
prevalent for males or easier to disclose. The confidential nature of this study enabled 117 young people to self-report CSA with more females reporting CSA compared with males. Studies suggest male survivors are less likely to seek help (Briere and Elliott 2003) and that CSA in males is a neglected area of study (Romano and De Luca 2001), which leads to reduced prevalence figures. While there are studies suggesting young males disclose CSA less often than young females (Jackson et al., 2013), they also suggest it becomes harder to disclose as they grow older: however, the current study found young males became more able to report CSA as they grew older.

Young survivors in this study, who had experienced confidentiality of services, said they could talk openly and honestly for the first time, without fear of negative consequences. Several expressed relief, a loss of isolation and being in control. Being able to openly talk about abuse, after being silenced for so long, was a big step. This was opposite to the loss of trust and control, retraction of abuse and sense of betrayal expressed by young people in this study who shared their experience of having their confidentiality broken. The issue of control is important to young people (Barter 2005), with young survivors in this study talking about the negative consequences and loss of control that resulted from confidentiality being broken.

The current study introduces a unique perspective suggesting that loss of confidentiality might lead to retraction of CSA allegations. It shows several factors involved including: information sharing, police investigation, unbearable stress and not wanting to get the offender into trouble. A significant number of survivors $(n=17)$ retracted CSA allegations rather than suffer negative consequences of disclosure '...I ended up saying that I had made it all up' (girl aged 15). According to Malloy et al. (2016), it is difficult to know all the factors leading to retraction, due to lack of evidence. But they found that the social context and not being believed or supported by caregivers influenced retraction. Further research is needed (Malloy \& Mugno 2016) to more fully understand the complex factors involved in confidentiality and retraction.

For those young people in this study who had previously disclosed abuse, often without intention to report, reactions were often immediate, with adults reporting to authorities, sometimes without telling the young person. There is a common assumption that it is in the best interests of CSA survivors and society for CSA to be reported immediately in the hope of prosecutions and life improvements (McElvaney 2015). However, this assumption is not backed up by research evidence. Most CSA cases do not go to court, and fewer still result in a successful conviction (Horvath et al. 2014; Children's Commissioner for England, 2015). This pattern is similar for other forms of sexual violence (Gallagher 2009; Allnock 2016). Additionally, although recent crime statistics show more cases going forward to the court stage, the rate of successful prosecutions is falling (Allnock 2015). For those cases that do progress through CJS, there are widespread systemic failures in prioritising the welfare of young people (Horvath et al. 2014; Allnock 2015), often leading to further harm. Warrington et al. (2017) state that statutory interventions experienced by young CSA survivors were nearly all described as damaging and presenting new difficulties for young survivors, including multiple fears and sometimes loss. Young people in the current study described loss of trust and relationships resulting from breaches of their confidentiality.

It is important to minimise any implicit notion that children are responsible for their own protection from abuse (Smallbone et al. 2008). However, it is also recognized that increasing knowledge about abuse and self-protection skills can lead to gains in self- 
protective behaviour such as disclosing or seeking help (Topping and Barron 2009; Walsh et al. 2015). This current study suggests that not all parents are protective and not all young people, including those in local authority care, are protected. Confidentiality was important to these young people to keep control and protect themselves. Professionals' assumptions that parents and care staff were safe people led to increased difficulties for some young people when their information was shared.

Confidential services are currently rare in the UK, yet, according to this study and others (Featherstone and Evans 2004), young CSA survivors' rate confidential services as important. The literature over many years mainly with adult survivors has described the same barriers to disclosing abuse, with key features being fear of CPS and CJS. Given that abuse disclosures are always dealt with through investigation and CJS in the UK, if young people do not wish this, then they cannot disclose to authorities. In addition, attitudes of professionals towards young people's participation in decisionmaking continue to be influenced by traditional child development models, and protectionist arguments are used to avoid transferring real power to young people (Winter 2006) thus limiting young people's opportunities to influence decisions that affect them (Luckock et al. 2007). None of this contributes to building the trust and confidence young CSA survivors need to talk about abuse, and as a result, they often remain silent into adulthood.

Young people's participation rights are often compromised if they are judged to be vulnerable or the research subject sensitive and their right to participation is denied (Powell and Smith 2009). Alderson and Morrow (2004) suggest that a better balance between participation and protection is needed to hear children's voices without exploiting or silencing them. Young people also believe that they should be able to participate in decision-making, and listening carefully to their views is important in resolving tensions between their participation and protection (Cashmore and Parkinson 2009).

The involvement of young survivors as researchers through PAR provided a privileged opportunity to learn from their perspectives and offered a distinctive lens through which to understand the data from a unique and insightful perspective. Young researchers reported an increase in self-esteem and confidence. While involved in the research, the lives of the young researchers changed in significant and positive ways including returning to education, securing paid work and volunteering. This suggests being involved as young researchers was a positive experience, though perhaps other factors in their lives were influential too. No one reported any negative experiences.

\section{Limitations}

Abuse survivors' engagement as researchers created bias based on experiential knowledge. This was addressed through being explicit about the unique perspectives of being survivors as well as by utilizing mixed method approaches to allow for triangulation. The use of PAR encouraged different interpretations enabling a wide range of young people's perspectives to be expressed. Transparency of methods, analysis and use of exemplar quotes allows readers to analyse data and form their own opinions.

This study contacted young CSA survivors through $18 \mathrm{u}$ for convenience and sensitivity. Therefore the data may not represent the views of survivors who do not use $18 \mathrm{u}$ services. 
There were limitations with young people preferring to talk online. Lack of facial and body language meant that some meaning may have been missed. There we advantages, however, as the methods increased young people's anonymity. It is possible that some meanings were misinterpreted because of differences in age and culture. It is also possible that the range of experience and skills held by researchers combined to create a unique and competent research team.

\section{Conclusion}

Young CSA survivors unknown to CPS wanted higher levels of confidentiality than they currently receive from services. Further, young people reported that lack of confidentiality was one of the reasons they did not disclose abuse to professionals. This study highlighted the importance of young CSA survivors building relationships based on trust in confidentiality, being believed and having adults available with a positive attitude who would not judge them. Staying in control was also important to the young survivors. Current CPS in the UK do not lend themselves to this, as prosecution is a key aim. It also tends not to prioritise the support needs of young people and can be harmful, while not always ending abuse. All of this, including abuse retractions and the reluctance of young survivors to disclose abuse to authorities, would indicate that something different is needed. Having the opportunity to access confidential services could help meet the needs of many young CSA survivors better and possibly lead to more positive outcomes.

Indications are that young CSA survivors, unknown to CPS, do not trust these systems in the UK. This perspective, coupled with survivors' powerlessness when faced with professionals and protectionist arguments prevents young people remaining in control or gaining any say in decisions affecting them.

Involving young CSA survivors as researchers in research with other young CSA survivors allowed them to address issues that had affected them directly and brought their own expertise into the study in a way that has not been achieved before now. Survivors conducting research led to novel foci of research and outcomes. All young researchers reported feeling empowered and increased self-esteem and self-confidence.

\section{Recommendations for Practice and Policy}

This study has highlighted the importance of listening to young CSA survivors about their views on confidentiality. Young people in this study asked for greater confidentiality to be able to trust, start to talk about abuse and get information. Further research is recommended to be carried out to confirm or refute this finding. It is recommended that professionals think about what confidentiality means for young people and the importance of it to them and that professionals consider carefully the balance between young people's needs for and right to confidentiality and the need to protect young people. 


\section{Recommendations for Future Research}

The current research was confined to survivors within one agency and there is now a need to seek the views of young survivors in other agencies. There is also a need for research into the needs of young male CSA survivors as so little is known about their needs. This research has added new insight into the causes of retraction, and further research to explore these findings would add to the growing body of knowledge. Furthermore, research exploring the link between confidentiality and retraction may help increase knowledge and understanding of any relationship between these. Further research using PAR focusing on the same research question, with young CSA survivors, is recommended to assess whether the results are replicated or not.

\section{Compliance with Ethical Standards}

Research approval was granted by the University of Dundee Research Ethics committee (reference: E2016-12) to explore the views of young CSA survivors whose abuse was unknown to child protection agencies on confidentiality.

Conflict of Interest The authors declare that they have no conflict of interest.

Open Access This article is distributed under the terms of the Creative Commons Attribution 4.0 International License (http://creativecommons.org/licenses/by/4.0/), which permits unrestricted use, distribution, and reproduction in any medium, provided you give appropriate credit to the original author(s) and the source, provide a link to the Creative Commons license, and indicate if changes were made.

\section{References}

Alderson, P., \& Morrow, V. (2004). Ethics, social research and consulting with children and young people. London: Barnardos.

Allnock, D. (2015). Child maltreatment: how can friends contribute to safety? Safer Communities, 14(1), 2736. https://doi.org/10.1108/SC-02-2015-0005.

Allnock, D. (2016). Exploring the relationship between neglect and adult-perpetrated intra-familial child sexual abuse: evidence Scope 2. Totnes. Research in practice. London: NSPCC.

Ashworth, P. (2003). The origins of qualitative psychology. In J. Smith (Ed.), Qualitative psychology: a practical guide to research methods. Thousand Oaks: Sage.

Barter, K. (2005). Alternative approaches to promoting the health and well-being of children. In M. Ungar (Ed.), Handbook for working with children and youth: pathways to resilience across cultures and contexts (pp. 343-356). Thousand Oaks, CA: Sage.

Beauchamp, T. L., \& Childress, J. (1994). Principles of biomedical ethics (4th ed.). Oxford: Oxford University Press.

Beazley, H., \& Ennew, J. (2006). Participatory methods and approaches: tackling the two tyrannies. In V. Desai \& R. Potter (Eds.), Doing development research (pp. 189-199). Thousand Oaks: Sage.

Beresford, P. (2010). Re-examining relationships between experience, knowledge, ideas and research: a key role for recipients of state welfare and their movements. Social Work \& Society, 8(1), 6-21 https://www. socwork.net/sws/article/view/19/56.

Beresford, P., \& Boxall, K. (2013). Service user research in social work and disability studies in the United Kingdom. Disability \& Society, 28(5), 587-600. https://doi.org/10.1080/09687599.2012.717876.

Beresford, P., \& Boxall, P. (2014). Where do service users' knowledges sit in relation to professional and academic understandings of knowledge? In P. Staddon, Mental health service users in research: critical sociological perspectives (pp. 69-86). Policy Press online: Bristol. 
Bergström, K., Jonsson, L., \& Shanahan, H. (2010). Children as co-researchers voicing their preferences in foods and eating: methodological reflections. International Journal of Consumer Studies, 34(2), 183-189. https://doi.org/10.1111/j.1470-6431.2009.00843.x.

Bevan, A. (2013). Creating communicative spaces in an action research study. Nurse Researcher, 21(2), 14 17. https://doi.org/10.7748/nr2013.11.21.2.14.e347.

Bisman, C. (2008). Personal information and the professional relationship: issues of trust, privacy and welfare. In C. Clark \& J. McGhee (Eds.), Private and confidential? Handling personal information in the social and health services (pp. 17-34). Bristol: Policy Press.

Boruch, R., \& Cecil, J. (1979). Assuring the confidentiality of social research data. Philadelphia: University of Pennsylvania Press.

Braun, V., \& Clarke, C. (2006). Using thematic analysis in psychology. Qualitative Research in Psychology, 3(2), 77-101. https://doi.org/10.1191/1478088706qp063oa.

Briere, J., \& Elliott, D. (2003). Prevalence and psychological sequelae of self-reported childhood physical and sexual abuse in a general population sample of men and women. Child Abuse \& Neglect, 27(10), 12051222. https://doi.org/10.1016/j.chiabu.2003.09.008.

Cashmore, J., \& Parkinson, P. (2009). Children's participation in family law disputes: the views of children, parents, lawyers and counsellors. Family Matters, (82), 15-21.

Children's Commissioner for England. (2015). Protecting children from harm: a critical assessment of child sexual abuse in the family network in England and priorities for action. London: Office of the Children's Commissioner for England.

Clemens, E., \& Mason, S. (2008). Participatory research for rape survivor groups. A model for practice. Affilia: Journal of Women and Social Work, 23(1), 66-76. https://doi.org/10.1177/0886109907310459.

Crisma, M., Bascelli, E., Paci, D., \& Romito, P. (2004). Adolescents who experienced sexual abuse: fears, needs and impediments to disclosure. Child Abuse \& Neglect, 28(10), 1035-1048. https://doi.org/10.1016 /j.chiabu.2004.03.015.

Dhai, A., \& Payne-James, J. (2013). Problems of capacity, consent and confidentiality. Best Practice \& Research Clinical Obstetrics and Gynaecology., 27(1), 59-75. https://doi.org/10.1016/j. bpobgyn.2012.08.007.

Ely, M., Vinz, R., Downing, M., \& Anzul, M. (1997). On writing qualitative research: living by words. Abigdon-on-Thames: Routledge Falmer Publishing.

Featherstone, B., \& Evans, H. (2004). Children experiencing maltreatment: who do they turn to. London: NSPCC.

Flatley, J. (2016). Abuse during childhood: Findings from the crime survey for England and Wales, year ending March 2016. Newport: Office for National Statistics.

Gallagher, B. (2009). Child sexual abuse: informed or in fear? Criminal Justice Matters, 77(1), 6-7. https://doi.org/10.1080/09627250903138936.

Gekoski, A., Horvath, M., \& Davidson, J. (2016). The effectiveness and impact of the child protection and criminal justice systems in cases of intra-familial child sexual abuse. Journal of Criminological Research, Policy and Practice, 2(1), 54-66. https://doi.org/10.1108/JCRPP-06-2015-0023.

Gilligan, P. (2016). Turning it around: what do young women say helps them to move on from child sexual exploitation? Child Abuse Review, 25(2), 115-127. https://doi.org/10.1002/car.2373.

Gray, C., \& Winter, E. (2011). Hearing voices: participatory research with preschool children with and without disabilities. European Early Childhood Education Research Journal, 19(3), 309-320. https://doi. org/10.1080/1350293X.2011.597963.

Hallett, S. (2013). Child sexual exploitation in South-East Wales: problems and solutions from the perspectives of young people and professionals, http://orca.cf.ac.uk/58234/

Hébert, M., Tourigny, M., Cyr, M., McDuff, P., \& Joly, J. (2009). Prevalence of childhood sexual abuse and timing of disclosure in a representative sample of adults from the province of Quebec. The Canadian Journal of Psychiatry, 54(9), 631-636. https://doi.org/10.1177/070674370905400908.

Hill, L., \& Wales, A. (2011). Roundtable report. Finding the balance: children's right to confidentiality in an age of information sharing. Edinburgh: Children First.

Hiriscau, J., Stingelin-Giles, N., Stadler, C., Schmeck, K., \& Reiter-Theil, S. (2014). A right to confidentiality or a duty to disclose? Ethical guidance for conducting prevention research with children and adolescents. European Child \& Adolescent Psychiatry, 23(6), 409-416. https://doi.org/10.1007/s00787-014-0526-y.

Horvath, M., Davidson, J., Grove-Hills, J., Gekosk, A., \& Choak, C. (2014). It's a lonely journey: a rapid evidence assessment on intra-familial child sexual abuse. Project report. London: Middlesex University.

Im, E., \& Chee, W. (2006). An online forum as a qualitative research method: practical issues. Nursing Research, 55(4), 267-273 https:/www.ncbi.nlm.nih.gov/pmc/articles/PMC2491331/. 
Jackson, S., Newall, E., \& Backett-Milburn, K. (2013). Children's narratives of sexual abuse. Child and Family Social Work, 20(3), 322-332. https://doi.org/10.1111/cfs.12080.

Jensen, T., Gulbrandsen, W., Mossige, S., Reichelt, S., \& Tjersland, O. (2005). Reporting possible sexual abuse: a qualitative study on children's perspectives and the context for disclosure. Child Abuse \& Neglect, 29(12), 1395-1413. https://doi.org/10.1016/j.chiabu.2005.07.004.

Jones, A. (2004). Involving children and young people as researchers. In S. Fraser, V. Lewis, S. Ding, M. Kellett, \& C. Robinson (Eds.), Doing research with children and young people. London: Sage.

Jonzon, E., \& Lindblad, F. (2004). Disclosure, reactions and social support: findings from a sample of adult victims of child sexual abuse. Child Maltreatment, 9(2), 190-200. https://doi.org/10.1177 $/ 1077559504264263$.

Kellett, M. (2005). Children as active researchers: A new research paradigm for the $21^{\text {st }}$ century? Published online by ESRC National Centre for Research Methods, NCRM/003 www.ncrm.ac.uk/publications.

Kellett, M. (2009). Children as researchers: issues, impact and contribution to knowledge. Counting Children in $2^{\text {nd }}$ Inter. Sydney: Conference of Child Indicators.

Kellett, M. (2010). Small shoes, big steps! Empowering children as active researchers. American Journal of Community Psychology, 46(1-2), 195-203. https://doi: https://doi.org/10.1007/s10464-010-9324-y

Kesby, M., Kindon, S., \& Pain, R. (2005). 'Participatory' approaches and diagramming techniques. In R. Flowerdew \& D. Martin (Eds.), Methods in human geography: a guide for students doing a research project (2nd ed., pp. 144-166). London: Pearson Education.

Koggel, C. (2003). Confidentiality in the liberal tradition: a relational critique. In C. Koggel, A. Furlong, \& C. Levin (Eds.), Confidential relationships. Amsterdam: Rodopi.

Lefevre, M., Hickle, K., Luckock, B., \& Ruch, G. (2017). Building trust with children and young people at risk of child sexual exploitation: the professional challenge. British Journal of Social Work, 47(8), 24562473. https://doi.org/10.1093/bjsw/bcw181.

London, K., Bruck, M., Wright, D., \& Ceci, S. (2008). Review of the contemporary literature on how children report sexual abuse to others: findings, methodological issues, and implications for forensic interviewers. Memory, 16(1), 29-47. https://doi.org/10.1080/09658210701725732.

Luckock, B., Lefevre, M., \& Tanner, K. (2007). Teaching and learning communication with children and young people: developing the qualifying social work curriculum in a changing policy context. Child and Family Social Work, 12(2), 192-201. https://doi.org/10.1111/j.1365-2206.2006.00465.x.

Lundy, L., McEvoy, L., \& Byrne, B. (2011). Working with young children as co-researchers: an approach informed by the United Nations Convention on the Rights of the Child. Early Education \& Development, 22(5), 714-736. https://doi.org/10.1080/10409289.2011.596463.

Lyon, T. (2007). False denials: overcoming methodological biases in abuse disclosure research. In M. Pipe, M. Lamb, Y. Orbach, \& A. Cederborg (Eds.), Child sexual abuse: disclosure, delay, and denial (pp. 41-62). Mahwah: Lawrence Erlbaum Associates.

Malloy, L., \& Mugno, A. (2016). Children's recantation of adult wrongdoing: an experimental investigation. Journal of Experimental Child Psychology, 145, 11-21. https://doi.org/10.1016/j.jecp.2015.12.003.

Malloy, L., Mugno, A., Rivard, J., Lyon, T., \& Quas, J. (2016). Familial influences on recantation in substantiated child sexual abuse cases. Chid Maltreatment, 21(3), 256-261. https://doi.org/10.1177 /1077559516650936.

Mascheroni, G., \& Ólafsson, K. (2014). Net children go mobile: risks and opportunities (second edition ed.). Milano: Educat.

Matthew, L., \& Barron, I. (2015). Participatory action research on help seeking behaviours of self-defined ritual abuse survivors: a brief report. Journal of Child Sexual Abuse, 24(4), 429-443. https://doi. org/10.1080/10538712.2015.1029104.

Matthew, L., Barron, I., \& Hodson, A. (2019). Perspectives of young child abuse survivors on confidentiality: an exploratory literature review. Journal of Child Sexual Abuse, 28(3), 280-300.

McElvaney, R. (2015). Disclosure of child sexual abuse: delays, non-disclosure and partial disclosure. What the research tells us and implications for practice. Child Abuse Review, 24(3), 159-169. https://doi. org/10.1002/car.2280.

Morgan, R. E., \& Kena, G. (2018). Criminal Victimization, 2016: Revised. Washington, DC: Bureau of Justice Statistics.

Moy, P., \& Murphy, J. (2016). Problems and Prospects in Survey Research. Journalism \& Mass Communication Quarterly, 93(1), 16-37. https://doi.org/10.1177/1077699016631108.

Munro, E. (2010). The Munro review of child protection. Part one. A system's analysis. Norwich: The Stationary Office.

Munro, E. (2011a). The Munro review of child protection. Interim report. The child's journey. Norwich: The Stationary Office. 
Munro, E. (2011b). The Munro review of child protection: final report. A child-centered system. Norwich: The Stationary Office.

Orne, J., \& Bell, M. (2015). An invitation to qualitative fieldwork. New York, USA: Routledge.

Pereda, N., Abad, J., \& Guilera, G. (2016). Lifetime prevalence and characteristics of child sexual victimization in a community sample of Spanish adolescents. Journal of Child Sexual Abuse, 25(2), 142-158. https://doi.org/10.1080/10538712.2016.1123791.

Piano-Clark, V., \& Creswell, J. (2008). The mixed method reader. London: Sage Publications.

Plotnikoff, J., \& Woolfson, R. (2009). Measuring up? Evaluating implementation of Government commitments to young witnesses in criminal proceedings. London: National Society for the Prevention of Cruelty to Children.

Powell, M., \& Smith, A. (2009). Children's participation rights in research. Childhood, 16(1), 124-142. https://doi.org/10.1177/0907568208101694.

Priebe, G., \& Svedin, C. (2008). Child sexual abuse is largely hidden from the adult society: An epidemiological study of adolescents' disclosures. Child Abuse \& Neglect, 32(12), 1095-1108. https://oi. org/10.1016/j.chiabu.2008.04.001.

Punch, S. (2002). Interviewing strategies with young people: the 'secret box', stimulus material and task-based activities. Children \& Society, 16, 45-56. https://doi.org/10.1002/chi.685.

Punch, K. (2009). Introduction to research methods in education. London: Sage.

Radford, L., Corral, S., Bradley, C., Fisher, H., Basset, C., \& Howatt, N. (2011). Child abuse and neglect in the UK today. London, UK: NSPCC.

Reitsema, A., \& Grietens, H. (2016). Is anybody listening? The literature on the dialogical process of child sexual abuse disclosure reviewed. Trauma, Violence, \& Abuse, 17(3), 330-340. https://doi.org/10.1177 $/ 1524838015584368$.

Romano, E., \& De Luca, R. (2001). Male sexual abuse: a review of effects, abuse characteristics, and links with later psychological functioning. Aggression and Violent Behavior, 6(1), 55-78. https://doi. org/10.1016/S1359-1789(99)00011-7.

Rose, D. (2009). Survivor-produced knowledge. In A. B. Sweeney, P. Faulkner, A. M. Nettle, \& D. Rose (Eds.), This is survivor research. Ross-on-Wye: PCCS Books.

Silver, C. (2011). Participatory approaches to social research. In N. Gilbert (Ed.), Researching social life. London: Sage Publications.

Sjöberg, R., \& Lindblad, F. (2002). Limited disclosure of sexual abuse in children whose experiences were documented by videotape. The American Journal of Psychiatry, 159(2), 312-314. https://doi.org/10.1176 /appi.ajp.159.2.312.

Smallbone, S., Marshall, W., \& Wortley, R. (2008). Preventing child sexual abuse: evidence, policy and practice. Devon, Willan Publishing.

Smeaton, E. (2013) Running from hate to what you think is love: the relationship between running away and child sexual exploitation, Barkingside, Barnardo's. https://www.barnardos.org.uk/15505_cse_running _ from_hate_21_web.pdf.

Staller, K., \& Nelson-Gardell, D. (2005). "A burden in your heart": lessons of disclosure from female preadolescent and adolescent survivors of sexual abuse. Child Abuse \& Neglect, 29(12), 1415-1432. https://doi.org/10.1016/j.chiabu.2005.06.007.

Thomas, N., Murray, E., \& Rogstad, K. (2006). Confidentiality is essential if young people are to access sexual health services. International Journal of STD \& AIDS, 17(8), 525-529. https://doi.org/10.1258 /095646206778145686.

Topping, K. J., \& Barron, I. G. (2009). School-based child sexual abuse prevention programs: a review of effectiveness. Review of Educational Research, 79(1), 431-463. https://doi.org/10.3102 $/ 0034654308325582$.

Ullman, S. (2007). Relationship to perpetrator, disclosure, social reactions, and PTSD symptoms in child sexual abuse survivors. Journal of Child Sexual Abuse, 16(1), 19-36. https://doi.org/10.1300/J070v16 n01_02.

Ungar, M., Barter, K., McConnell, S., Tutty, L., \& Fairholm, J. (2009). Patterns of abuse disclosure among youth. Qualitative Social Work, 8(3), 341-356. https://doi.org/10.1177/1473325009337842.

Walsh, K., Zwi, K., Woolfenden, S., \& Shlonsky, A. (2015). School-based education programmes for the prevention of child sexual abuse. Evidence-Based Child Health: A Cochrane Review Journal, 4.

Warrington, C., Beckett, H., Ackerley, E., Walker, M., \& Allnock, D. (2017). Making noise: children's voices for positive change after sexual abuse. Children's experiences of help-seeking and support after sexual abuse in the family environment. Dedford: The international Centre, University of Bedfordshire. 
Weinstein, H. (2014). Victims, transitional justice and social reconstruction. Who is setting the agenda? In I. Vanfraechem, A. Pemberton, \& F. Ndahinda (Eds.), Justice for victims. Perspectives on rights, transition and reconciliation. New York: Routledge.

Winter, K. (2006). Widening our knowledge concerning young looked after children: the case for research using sociological models of childhood. Child \& Family Social Work, 11(1), 55-64. https://doi. org/10.1111/j.1365-2206.2006.00385.x.

Woodyatt, C., Finneran, C., \& Stephenson, R. (2016). In-person versus online focus group discussions: a comparative analysis of data quality. Qualitative Health Research, 26(6), 741-749. https://doi. org/10.1177/1049732316631510.

Ybarra, M., DuBois, L., Parsons, J., Prescott, T., \& Mustanski, B. (2014). Online focus groups as an HIV prevention program for gay, bisexual and queer adolescent males. AIDS Education and Prevention, 26(6), 554-564. https://doi.org/10.1521/aeap.2014.26.6.554.

Zajac, R., O’Neill, S., \& Hayne, H. (2012). Disorder in the courtroom? Child witnesses under crossexamination. Developmental Review, 32(3), 181-204. https://doi.org/10.1016/j.dr.2012.06.006.

Publisher's Note Springer Nature remains neutral with regard to jurisdictional claims in published maps and institutional affiliations.

\section{Affiliations}

\section{Laurie Matthew ${ }^{1} \cdot$ Ian Barron ${ }^{2} \cdot$ Ann Hodson $^{3}$}

\section{Ian Barron}

ibarron@umass.edu

Ann Hodson

a.v.hodson@dundee.ac.uk

1 Eighteen And Under, 1 Victoria Road, Dundee DD1 1EL, UK

2 College of Education, University of Massachusetts, UMassAmherst, 813 North Pleasant Street, Amherst, MA 01003, USA

3 University of Dundee, Nethergate, Dundee DD1 4HN, UK 